\title{
AIIIIEMIIIR̂A|FH
}

http://dx.doi.org/10.4322/2316-1329.039

Contemporânea

v. 7, n. 2 p. $313-340$

Jul.-Dez. 2017

Dossiê

\section{Realizing Social Rights: The Material Impacts of Constitutional Entrenchment}

Evan Rosevear'

Abstract: Using data on the constitutional protection of social rights in 195 countries from 2000-2015 and controlling for economic, political, and demographic variables, I found moderately strong evidence that the right to health leads to increased public expenditures on healthcare but mixed evidence in relation to health outcomes, limited evidence of that the right to education improves primary school enrolment levels in non-civil law jurisdictions, and no correlation between the right to social security and income inequality. Contrary to expectations, I also found that ICESCR ratification is positively associated with declining infant mortality rates.

Keywords: Health, Education, Social Security, Comparative Constitutional Law, Social Rights

\section{Introduction}

Social rights have attained substantial legal and discursive currency. They formally guarantee access to healthcare, education, social security, and to many other benefits. They feature prominently in flagship international human rights instruments such as the United Nations Declaration of Human Rights (UNDHR) and the International Covenant on Economic, Social, and Cultural Right (ICES$\mathrm{CR}$ ) as well as human rights discourse more broadly. They have also become

1 Faculty of Law and Department of Political Science - University of Toronto - evan.rosevear@utoronto.ca 
a standard feature of constitutions of contemporary nation-states. The earliest appearance of a social right in a national constitution appears to have been the right to education in the short-lived Haitian Constitution of $1805 .{ }^{2}$ Although a relatively anomalous occurrence for the next century and a half, since the end of the Second World War these rights have become a standard feature of national constitutions: at beginning of 2015 more than eighty percent guaranteed the right to education and more than sixty percent the right to health as either aspirational or justiciable guarantees. Like many other features of contemporary constitutions, there is a marked similarity in the language and structure of social rights provisions across disparate jurisdictions. This is not especially surprising in view of similar source material - particularly the UNDHR and ICESCR - and the global prevalence of constitutional borrowing (Choudhry, 2006; Elkins, 2010; Perju, 2012).

Representing both an aspect of the broader growth of global constitutionalism and a concrete manifestation of human rights guarantees, this trend has attracted significant scholarly attention. The focus has been on individual legal cases or the fortunes of particular social movements using litigation as a primary strategy for advancing their cause (Scott; Alston, 2000; Heywood, 2009; Scherer, 2004), the treatment of a particular right (Coutinho, 2014; Hohmann, 2013), and the development of jurisprudence in a given apex court (Roux, 2013; Wang, 2015)"event-place":"Cambridge','ISBN":"978-1-107-61906-7','callnumber":"KTL2620 .R68 2013X','shortTitle":"'The politics of principle"', author" :[\{“family":”Roux"',given”:”Theunis”\}],'issued”:\{“date-parts”:[[“2013”]]\}\}\},\{“id” :19791,"uris":[“http://zotero.org/users/45401/items/5MSDCDFQ"],"uri”:[“http:// zotero.org/users/45401/items/5MSDCDFQ"],"itemData”:\{“id":19791,"type":"arti cle-journal'"'title":"Right to Health Litigation in Brazil: The Problem and the Institutional Responses"',container-title":"Human Rights Law Review'"'page":"617-641"'”volume":"15","issue":" 4","source":"hrlr.oxfordjournals.org.myaccess. library.utoronto.ca','abstract":"'This article first analyses how courts, by applying the right to health as a trump against rationing decisions, have become a relevant healthcare policymaker in Brazil. Based on empirical findings, it argues that right to health litigation makes the Brazilian public health system less fair and efficient. It then discusses three responses to the negative impact of litigation on the health system: the public hearing held by the Supreme Federal

2 "Within each military division a public school shall be established for the instruction of youth." (Corbett 1999: General Dispositions, Act 19). The 1828 Peruvian constitution was more explicit: "[The Constitution] also guarantees gratuitous primary instruction to all Citizens; the Institutions in which may be taught the Sciences, Literature, and the Arts ..." ("Political Constitution of the Peruvian Republic, 1828" 1832, art. 171) 
Court and the test established thereafter; the recommendations by the National Council of Justice aimed at building courts' institutional capacity; and Federal Law 12.401/11, which created a new health technology assessment system. Based on a comparative institutional analysis, it concludes that the latter response is the most adequate because it keeps the substantial decisions on the allocation of healthcare resources in the institution that has better capacity to make them and facilitates the judicial control of procedure.'”'DOI":"10.1093/ hrlr/ngvo25'"'ISSN":"1461-7781, 1744-1021"','shortTitle":"Right to Health Litigation in Brazil'"'journalAbbreviation":"Human Rights Law Review','language":"

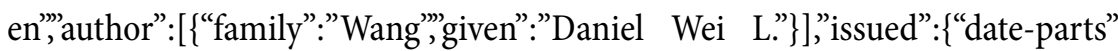
:[[“2015,"12,1]]\}\}\}],"schema":"https://github.com/citation-style-language/sche$\mathrm{ma} / \mathrm{raw} / \mathrm{master} / \mathrm{csl}$-citation.json” $\}$. It provides detailed descriptions of litigation and advocacy processes, contextualizes the application of social rights, and offers numerous insights about whether and when they may be effective (Gauri; Brinks, 2008; Langford, 2008; Young, 2012; King, 2012; Rodríguez Garavito; Franco, 2015). What have only recently begun to emerge, however, are attempts to examine the efficacy of these guarantees in a systematic and comparative manner. Does, for example, a constitutional right to health lead to an improvement in the health of a jurisdiction's citizens? Does the right to education lead to more children in school? In short, do they work? Moreover, while the phrasing of these rights and the manner of their constitutionalization share many similarities, this is no guarantee that they will be interpreted in a similar fashion across different jurisdictions, let alone yield similar policy outputs and distributive outcomes. A second line of questioning, then, is whether the (in)efficacy of constitutional social rights is associated with specific legal, economic, or political circumstances.

In this piece, I endeavor to address these questions be analyzing the relationship of three social rights - to education, to health, and to social security - and public expenditures in the relevant areas as well as indicators of rights realization. To do so I employ data on the formal constitutional status of the three specified social rights guarantees in 195 countries from 2000-2015 in conjunction with relevant proxy and control variables. In doing so I find moderately strong evidence to suggest that the entrenchment of the right to health results in increased public expenditures on healthcare but limited evidence of improved health outcomes. The evidence with respect to social security is less clear. When entrenched as aspirational, the right to social security is associated with decreased post-tax and transfer income inequality; when entrenched as a justiciable right, the reverse is true, although the relationship is not particularly robust. I 
find no compelling evidence in support of the existence of a relationship in either direction between the right to education and public expenditures on education, and only limited evidence supporting improved educational outcomes. With respect to international human rights instruments, ICESCR ratification does not appear to have any effect on education or social security. It is, however, positively associated with declining infant mortality rates. In addition, the registration of a reservation by the ratifying country is negatively associated with mortality rates, life expectancy, and post-tax and transfer income inequality. Moreover, the magnitude of the reservation effect tends to be markedly greater than the positive effects of ratification.

\section{Literature and Theory}

\section{A. The Efficacy of International and Domestic Rights Guarantees}

It is only in the past few years that researchers have begun, quite tentatively, to move from the study of legal reasoning and judicial output - the text of court decisions - to the examination of substantive social outcomes-the extent to which rights entrenchment has resulted in material improvements for citizens of those countries. This work has developed out of slightly older body of research concerned with the impact of international human rights treaties. Early work in this area tended to focus on "negative" rights such as freedom from torture, respect for civil liberties, and gender representation. It failed to find a relationship between human rights treaties such as the International Covenant on Civil and Political Rights (ICCPR) and respect for human rights (Hathaway, 2002; Keith, 1999), leading to the conclusion that "international human rights treaties do little to encourage better practices and cannot stop many governments from a spiral of increasing repressive behavior, and may even exacerbate poor practices" (Hafner-Burton; Tsutsui, 2005: 1398). What these studies did do, was confirm the correlation of several other factors with respect for human rights. Supporting contemporary liberal-institutionalist theory, both democracy and wealth were positively correlated with respect for human rights, as was domestic involvement in international NGOs. They also suggested that population growth and civil war were negatively correlated with respect for human rights (Hafner-Burton; Tsutsui, 2005; Neumayer, 2005). In short, the first generation of studies on the impact of international human rights found no correlation between the ratification of human rights treaties and a decline in repressive behavior on the part of states. 
Similar findings have been made with respect to the correlation of human rights instruments and health-related outcomes (Palmer et al., 2009), and are echoed in the early large-N research on domestic social and economic rights guarantees. In a study of economic and social rights in 68 countries, Ben-Bassat and Dahan (2008) found some positive correlations between rights entrenchment and realization, but concluded that constitutional commitments regarding education and health were generally consistent with the "cheap talk" hypothesis in that they are of limited effect in terms of public policy or material outcomes. In a similar study based on 160 countries, Bjornskov \& Mchangama (2013)social and cultural rights (ESCRs found no compelling evidence of the positive impact of constitutionally entrenching rights to health, education, or social security, but did find evidence of adverse medium term effects on both education and inflation, leading them to conclude that "the historical experience since the 1960s shows that the introduction of [Economic Social and Cultural Rights] in national constitutions is, at best, inconsequential" (2013: 26)social and cultural rights (ESCRs.

Over time, scholars focusing on the international law have begun to suggest that the answer to whether human rights treaties have a positive effect is more complex than simply yes or no (Neumayer, 2005; Getgen; Meier 2009; Randolph et al. 2010)this article presents country scores and rankings based on the Economic and Social Rights Fulfillment Index (ESRF Index. Moving beyond explicit rights guarantees, Pinzon-Rondon at al.s (2015) study of 96 countries finds that "rule of law" is correlated with better performance in terms of infant and maternal mortality, cardiovascular and diabetes mortality rate, and life expectancy. However, the findings are not as robust as one might hope; the study is purely cross-sectional. Cole, using post-tax and transfer Gini coefficients as a proxy for respect for human rights, finds that "a normative commitment to socioeconomic rights as measured by long-term ICESCR membership independently reduces income inequality across a range of economically and politically disparate countries" (2015:383)"abstract":"Much research finds that human rights treaties fail to improve domestic practices unless governments are held accountable in some fashion. The implication is that noncompliance can be attributed to insincere commitments and willful disobedience. I challenge this claim for a core but overlooked treaty: the International Covenant on Economic, Social, and Cultural Rights (ICESCR. This, he argues, indicates that human rights treaties cannot be dismissed as merely "ceremony without substance" and to the extent they are moderated by domestic factors, those factors are economic-e.g., GDP-rather than 
political-e.g., leftist political power, union density-in nature. Conversely, Hoffman and Røttingen (2015) find that the effectiveness of human rights treaties appears to be restricted to the area of civil and political rights and contingent on domestic factors such as democracy, civil society mobilization, and judicial independence.

A similar trend has begun to emerge with respect to domestic constitutions as well. Arguing that existing work on the impact of the right to health does not sufficiently incorporate the influence of political institutions, Kavanagh promotes a more nuanced consideration of the impact of guaranteeing the right to health, particularly the manner in which "it both constrains and structures interactions within governments and between state, business, and private actors" (2016:332). Based on a cross-national analysis of 144 countries from 1970-2010, he finds that, although relatively small, once democracy, inequality, urbanization, and political violence are accounted for, the constitutionalization of the right to health is associated with a statistically significant improvement in under-5 mortality as well as an number of service delivery and expenditure indicators. Small-n studies have also suggested that a more nuanced understanding of the process is necessary to uncover the pro-poor redistributive impacts of social and economic rights (Brinks; Gauri, 2014).

At present, then, there is little in the way of consensus in the research into the impact of social rights guarantees in domestic constitutions as to whether they are effective in bring about material changes and what factors, if any, condition their effects. On the one hand, the "cheap talk" hypothesis suggests that social rights guarantees may be well intentioned, but are ineffectual in practice. However, a more recent set of studies complicates the matter by suggesting the possibility that international human rights instruments can directly influence social outcomes as well as introducing a variety of domestic political and economic factors as exerting magnifying and nullifying effects. While I cannot settle these issues here, I do hope to offer a modest contribution to that enterprise via the development of a basic model of social rights realization and then undertake an initial analysis involving a relatively short time frame that incorporates a broader selection of countries than has been previously undertaken using a novel classification of these rights. It is to these tasks I now turn.

\section{B. Theoretical Framework}

If we accept the idea that foundational legal institutions-be they the result of a colonizer's legal tradition (La Porta et al. 2008)economists have 
produced a considerable body of research suggesting that the historical origin of a country's laws is highly correlated with a broad range of its legal rules and regulations, as well as with economic outcomes. We summarize this evidence and attempt a unified interpretation. We also address several objections to the empirical claim that legal origins matter. Finally, we assess the implications of this research for economic reform.,'”journalAbbreviation":

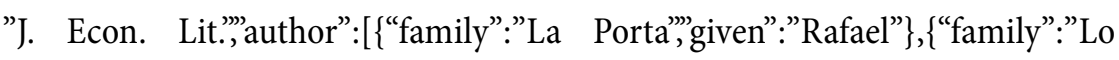
pez-de-Silanes",'given":"Florencio"\},\{“family":"Shleifer"',given":"Andrei"\}]," issued":\{“date-parts":[[“2008”]]\}\}\}],"schema”:"https://github.com/citation-style-language/schema/raw/master/csl-citation.json”\}, the nature of the colony (Acemoglu et al. 2001)with different associated institutions. In places where Europeans faced high mortality rates, they could not settle and were more likely to set up extractive institutions. These institutions persisted to the present. Exploiting differencesi n Europeanm ortalityr ates as an instrumenfto $r$ currenti nstitutions,we estimate large effects of institutions on income per capita. Once the effect of institutions is controlledfor, countries in Africa or those closer to the equator do not have lower incomes. (JEL 011, P16, P51, or timing and contingency in historical development (Esping-Andersen 1985; Gerschenkron 1962)"container-title":"Economic Backwardness in Historical Perspective: A Book of Essays"',publisher":"Belknap Press of Harvard University Press',"publisher-place":"Cambridge, Mass.","page":"5-30"', source":" Required'”'event-place”:"Cambridge, Mass.,'”author":[\{“family":" Gerschenkron'”,'given":"Alexander"\}],"issued”:\{“date-parts":[[“1962"]]\}\}\}],"sche ma":"https://github.com/citation-style-language/schema/raw/master/csl-citation.json"\} — are constitutive of a country's core legal-institutional framework, particularly with regard to established ideas about the relative priority of protecting against disorder and dictatorship (Djankov et al. 2003), there is little room for constitutions and constitutional rights to play an transformative role. Indeed, constitutions should be largely epiphenomenal. Rather than influencing law and policy, their content would be a product of the underlying legal tradition. More insidiously, social rights entrenchment intended to placate or curry favour with domestic or international interests (Renner, 2010 [1949]; Hathaway, 2007; Ben-Bassat; Dahan 2008), or induce the commitment of scarce civil society and opposition resources into litigation, a forum in which they are structurally disadvantaged, rather than more effective methods of seeking political change (Galanter, 1974; Rosenberg, 2008).

On other hand, in line with a dynamic concept of institutionalism, instances of constitutional change may serve as critical junctures (Baumgartner; Jones, 
1993) — or "constitutional moments" (Ackerman, 1991) — that have the potential to result in alterations of institutional trajectory (Pierson, 2000; Prado; Trebilcock, 2009). If this is the case, then constitutions should exert influence independent of a country's entrenched values and priorities.

To the extent constitutions are not merely declaratory or intentionally misleading, those that entrench social rights ought to have identifiable and near-immediate influence on both policy outputs-such as expenditures on social programs - and, after a short time, indicators of rights realization—such as life expectancy and literacy. Conversely the absence of any identifiable effect would support the "ceremony without substance" hypothesis. ${ }^{3}$ It is also possible that constitutional rights have direct effects where large quantities of individual claims do not result in policy changes but do results in substantial cash transfers service provision. The precedential nature of the common law system suggests that this is unlikely in jurisdictions whose institutional framework was built on common law. On the other hand, in civil law jurisdictions, particularly those in Latin America, the absence of binding precedent means that claims to realize rights need to be litigated on an individual basis. Moreover, case volumes are substantially higher and amparo and amparo-like proceedings allow individuals to quickly advance claims of rights violations at a relatively low cost (Brewer-Carías, 2008).

In Brazil, for example, between 1990 and 1998-in the wake of the new constitution-the number of health related new filings more than doubled to 7.5 million per year, and the number of appellate filings increased from 271,300 to 421,578 (Junquiera, 2003:81-82). In this case however, it is unclear what the direct distributive effects are, some scholars argue that there is a general trend toward a progressive redistribution of resources through this system;(Brinks; Gauri, 2012; Piovesan, 2008) others offer evidence of middle-class cooptation of the system and a net regressive impact (Ferraz, 2011; Silva; Terrazas, 2011)"container-title":"Litigating Health Rights: Can Courts Bring More Justice to Health?','collection-title":"Harvard Law School Human Rights Program Series'”,publisher":"Harvard University Press',"publisher-place":"Cambridge, Mass.,"'page":"76-102','event-place":"Cambridge, Mass.',"e

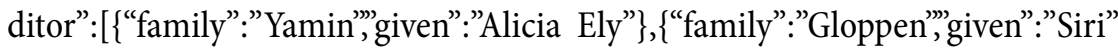

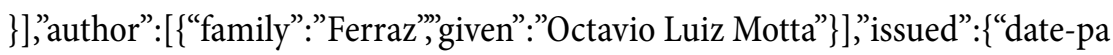

3 This should not be taken to suggests that constitutions and constitutional guarantees have no value or relevance. Independent of their direct influence, they may serve valuable social functions such as codifying and clarifying the governing principles of a legal system or serving as a touchstone of national identity and social cohesion (e.g., McCann, 1994; Rodríguez-Garavito, 2011). 
rts”:[[“2011”]]\}\}\},\{“id”:6951,"uris”:[“http://zotero.org/users/45401/items/ FGR7AWZX”],"uri”:[“http://zotero.org/users/45401/items/FGR7AWZX”],"it emData”:\{“id”:6951,"type":"article-journal'”'title":"Claiming the Right to Health in Brazilian Courts: The Exclusion of the Already Excluded?'”'container-title":"Law \& Social Inquiry"',page":"825-853',"volume":" 36 '"' issue":" 4",'sourc e":"Google Scholar','abstract":"The aim of this article is to test a widespread belief among Brazilian legal scholars in the area of social rights, namely, the claim that courts are an alternative institutional voice for the poor, who are usually marginalized from the political process. According to this belief, social rights litigation would be a means (supposedly "a better means" While right-to-health cases-particularly with respect to pharmaceutical provision-may have noticeable impacts on levels of realization, it is not clear that this is a general trend in the adjudication of rights in Latin America, let alone civil law countries generally. It is, I think, more likely that large volumes of individual litigation would elicit a policy response on the part of government if for no other reason than to avoid hemorrhaging resources or to provide the requisite services or transfers in a more cost-effective way (Borges, 2014). Nevertheless, to the extent that each individual claim needs to be litigated, we would expect constitutions to exert such influence as they have less on policy output and more on individual outcomes relative to common law systems.

The discussion above suggests a number of possible relationships among a jurisdiction's legal-institutional framework, constitutionalized economic and social rights, policy outputs, and policy outcomes. Insofar as they will be further analyzed herein, these relationships are graphically summarized in Figure 1. Key factors are enclosed in rectangular boxes and arrows indicate hypothesized causal relationships. The latter are differentiated in subsequent text using the particular $c_{n}$ with which they are associated. In terms of measurement: $c_{1}$ should capture a jurisdiction's underlying socio-political preferences, including those manifest in populist political processes; $c_{2}$ should reflect the more abstract and unpacked principles of the same; $c_{3}$ can be seen representative of change driven by elite, technocratic, or considered-popular preferences; $\mathrm{c}_{4 \rightarrow} \mathrm{c}_{5}$ should capture primarily community and social-movement driven change but likely includes some self-interested litigation as well; finally, $\mathrm{C}_{4 \rightarrow} \mathrm{C}_{8 \rightarrow} \mathrm{C}_{7}$ should capture predominantly individual, self-interested litigation albeit with spillover into altruistically supported individual claims where institutional factors such as those present in Brazil require litigation in every instance of a violation. 
Figure 1. A Model of Potential Legal-Institutional Impacts on Policy Outcomes

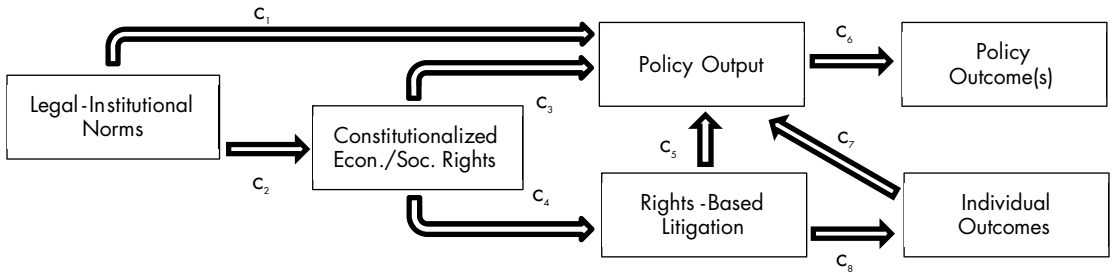

The remainder of this paper focuses on the effects of legal-institutional norms - manifest here as international treaty obligations as well as legal originsand constitutionalized social rights on relevant policy outputs and, in turn, the effects of those policy outputs on the relevant policy outcomes. Particularly insofar as implementation delays are accounted for in the models below (via lagged independent variables), the $c_{3}, c_{4 \rightarrow} c_{5}$, and the $c_{4 \rightarrow} c_{8 \rightarrow} c_{7}$ relationships are not separately accounted for in the subsequent analysis and the results must be interpreted in light of this.

\section{Data \& Analysis}

\section{A. Data}

The variables capturing the constitutional entrenchment of economic and social rights drawn from the TIESR dataset (Jung et al., 2014). These variables code whether a given right is absent, aspirationally, or justiciably entrenched in the relevant constitution. The TIESR dataset identifies eight social rights, three of which were selected for analysis: the rights to education, healthcare, and social security. ${ }^{4}$ In its original form, the TIESR data was cross-sectional; this analysis makes use of an updated dataset that incorporates annual data on the constitutional strength of social rights from 2000 to 2015. Where multiple changes occurred during the space of one year, coding was done in accordance with the constitution as in effect on January $1^{\text {st }}$. Changes were considered to have occurred on the date they came into force. Coding was conducted on the basis of the TIESR methodology. The timing and content of constitutional changes was identified primarily by reference to the Comparative Constitutions Project (Elkins et al., 2008), HeinOnline's World Constitutions Illustrated Database,

4 The remaining five - the rights to child protection, food and water, development, land, and housingwere excluded from the present analysis as no plausible proxies with sufficient breadth and depth of coverage could be located. 
and the Constitutions of the Countries of the World Database maintained by the Max Planck Institute for Comparative Public and International Law. In instances of uncertainty or ambiguity, reference was also made to the websites of the relevant national legislatures, executives and judiciaries as well as the Venice CODICES database and the University of Richmond's Constitution Finder.

As the impetus to constitutionally entrench social rights can be at least partly traced to the development and ratification of the International Covenant on Economic, Social and Cultural Rights (ICESCR), the status of each jurisdiction in relation to the ICESCR was incorporated into the dataset. For each country-year, three dummy variables were initially created based on the answers to the following questions: (1) had the Covenant been ratified? (2) had the country registered any declarations or reservations pertaining to the Covenant? (3) had one or more countries registered objections to those declarations or reservations? $\mathrm{Ba}-$ sed on the content of the reservations, a fourth dummy variable indicating the registration of a reservation specifically relating to education was also included.

Two typologies of "legal culture" were employed. The first was a simplified version of the JuriGlobe classification scheme which divides legal systems into those which are predominantly civil law or common law based as well as those which exhibit characteristics of both or are based solely on Islamic or Customary law (Perret et al., 2008). The five category legal origin classification used by Laporta and his collaborators was also included (La Porta et al., 2008)economists have produced a considerable body of research suggesting that the historical origin of a country's laws is highly correlated with a broad range of its legal rules and regulations, as well as with economic outcomes. We summarize this evidence and attempt a unified interpretation. We also address several objections to the empirical claim that legal origins matter. Finally, we assess the implications of this research for economic reform."',journalAbbreviation":"J. Econ. Lit."’’author":[\{“family":"La Porta','given”:"Rafael”\},\{“family”:”Lopez-de-

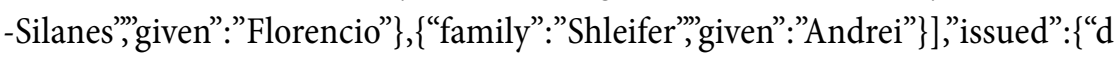
ate-parts":[[“2008”]]\}\}\}],"schema":"https://github.com/citation-style-language/ schema/raw/master/csl-citation.json"\} . ${ }^{6}$

5 With respect to (2) and (3), matters that related solely to the recognition of Israel as a state were not coded affirmatively. Ratification dates and the existence of declarations, reservations and objections are derived from the United Nations Treaty Collection. ("Chapter IV(3) International Covenant on Economic, Social and Cultural Rights: Ratification Status" 2014)

6 As coded herein, the JuriGlobe classification yields 122 civil law jurisdictions, 46 common law, and 25 mixed and non-European while the La Porta et al classification yields 63 UK (common law), 79 French, 34 Socialist, 7 German, and 4 Scandinavian jurisdictions. 
To the extent possible, variables representing both material realization and policy change in the relevant area are employed. The majority of the variables are drawn from the World Bank's World Development Indicators. For the right to education, policy is measured by public spending on education as a percentage of government spending and as a percentage of GDP. Realization is measured by youth literacy rate, as well as gross and net primary enrolment rates. ${ }^{7}$ Health policy is measured by public spending on health as a percentage of government spending and as a percentage of GDP. In accordance with standard practice, the realization of the right to health is measured by life expectancy at birth. Two additional measures of realization were also used: infant and under five mortality rates. Net (post tax and trasnfer) Gini, drawn from version 5.1 of Solt's (2016)the Standardized World Income Inequality Database (SWIID Standardized World Income Inequality Database, was used as a proxy for the realization of the right to social security.

A series of control variables were also included in each model. The natural log of GDP per capita (Constant 2010 USD) was used as a proxy for economic development and Freedom House's three-category democractic status-Free, Partly Free, and Not Free-was used as a proxy for democracy. Although there are some concerns about the normative content of the Worldwide Governance Indicators, the Political Stability variable was used as a proxy for the absence of civil unrest, the Rule of Law variable as a proxy for the capacity of the legal system, and Control of Corruption variable as a proxy for government inefficiency attributable to embezzlement or other illegal rent-seeking behavior (Kaufmann et al., 2010) Additionally, in line with both Bjørnskov and Mchangama (2013) social and cultural rights (ESCRs and Cole (2013), the natural log of country population is also included. Because of the fixed effects method employed in the statistical analysis regional control variables were not employed as they are time-invariant and would have been excluded from the models as a result of collinearity. ${ }^{8}$ Finally, in order to control for the effects of time, a dummy variable for each year of the analysis barring the first was included in each model. ${ }^{9}$

7 Bjørnskov and Mchangama (2013)social and cultural rights (ESCRs made use of the well-regarded BarroLee educational attainment dataset ("Barro-Lee Educational Attainment Dataset" n.d.). Although likely slightly less reliable than the Barro-Lee data, I have opted to use the World Development Indicators variables in preference for their broader coverage of jurisdictions and greater number of absolute (as opposed to interpolated) observations.

8 As indicated in the methods subsection below, it is possible to include time-invariant variables in fixed effects models via interaction terms. However, as regional variation was not a focus and the process is cumbersome to execute and interpret, it was not employed for regions herein. 


\section{B. Method}

The systematic differences between countries that do and do not constitutionally protect social rights mean that "one cannot simply compare average outcomes across human rights regimes” (Bjornskov; Mchangama, 2013:17)social and cultural rights (ESCRs. It is for this reason that, a fixed effects model was employed. ${ }^{10}$ The principal advantage this approach is that controls for jurisdiction-specific omitted variables, provided they are time invariant. It approximates randomized control and treatment group assignment by effectively using each jurisdiction as its own control. This enables one to exclude any static systematic differences that affect whether a particular jurisdiction does or does not entrench social rights. There are, however, two principle disadvantages to the method. First, it is possible that the effect of a time-invariant variable such as legal origin may change over time. However, a fixed effects model cannot account for this type of change. Second, if there is little within-case variation and large between-case variation, the estimates produced will tend to be very imprecise (Allison, 2009). As Table 1 indicates, there has been measurable, albeit limited, variation over time. This is likely to result in highly conservative standard error estimates. Additionally, to account for cross-sectional heteroskedasticity and serial correlation, standard errors were clustered by country.

Table 1. Change in Proportion of Constitutions Entrenching Social Rights, 2000-2015

\begin{tabular}{|c|c|c|c|c|c|c|c|c|c|}
\hline & \multicolumn{3}{|c|}{ Aspirational } & \multicolumn{3}{|c|}{ Justiciable } & \multicolumn{3}{|c|}{ Present } \\
\hline & 2000 & 2015 & $\begin{array}{l}\text { Change } \\
\text { (pct. pt) }\end{array}$ & 2000 & 2015 & $\begin{array}{l}\text { Change } \\
\text { (pct. pt) }\end{array}$ & 2000 & 2015 & $\begin{array}{l}\text { Change } \\
\text { (pct.pt) }\end{array}$ \\
\hline Education & $26.7 \%$ & $23.1 \%$ & $-3.6 \%$ & $46.7 \%$ & $57.9 \%$ & $11.3 \%$ & $73.3 \%$ & $81.0 \%$ & $7.7 \%$ \\
\hline Health & $28.2 \%$ & $27.2 \%$ & $-1.0 \%$ & $32.3 \%$ & $43.1 \%$ & $10.8 \%$ & $60.5 \%$ & $70.3 \%$ & $9.7 \%$ \\
\hline Social Security & $27.2 \%$ & $26.7 \%$ & $-0.5 \%$ & $31.3 \%$ & $42.1 \%$ & $10.8 \%$ & $58.5 \%$ & $68.7 \%$ & $10.3 \%$ \\
\hline
\end{tabular}

In the construction of the regression models, lagged independent variables were employed. Lagging is a process whereby the values of independent variables measured at a specified time are regressed against a values of the dependent variable measured at a subsequent time. For example, a lag of one year would imply that the value of an independent variable as measured in 2003 would be regressed against the value of the dependent variable in 2004. Doing so enables a more confident (although far from certain) inference about causality to be

10 Specifically, Stata's $x$ treg, and associated commands were used in conducting the statistical analysis. 
made based on the results. ${ }^{11}$ It is highly unlikely that a constitutionally entrenched social right will exert an immediate effect (i.e. in the year it was constitutionalized) on either policy or material realization. Models were replicated with 1,3 and 5 year lags. To a certain extent these time frames are arbitrary. However, the relatively limited time span of observations suggested that the lags should be relatively limited. In terms of expectations, to the extent they exist, policy effects are expected to manifest in the 1 and 3-year lagged models, while realization effects are expected in the 3 and 5 -year lags.

Eight models were generated for each dependent variable. ${ }^{12}$ The first two included dummy variables for the aspirational and justiciable variants the relevant right lagged one and then three years or three and then five years (as appropriate), the ICESCR dummy variables with the appropriate lag (four for education-related models and three for those pertaining to health and social security), and a standard battery of control variables: GDP, population, democratic status, political stability, rule of law, and corruption. The subsequent models consisted of the same variables, with interactions between entrenchment of the relevant right and the JuriGlobe typology (models three and four), the Laporta et al typology (models five and six) and the Democratic Status classification (models seven and eight). The interaction terms were employed as a means of approximating the effects of time-invariant factors in fixed effects models. To generate them, the aspirational and justiciable dummies for each of the rights were multiplied by the dummy variables for each of the legal origins excepting common law and democratic status excepting free, which served as the comparator categories.

There are two further points of note with respect to the interaction term approach. First, as with the fixed effects approach more generally, they are highly sensitive to limited in-case variation. This is more pronounced when the potential for variation is decreased by restricting the possibilities to a subset of cases as interaction does. For that reason, it is to be expected that many of the interaction terms will be excluded from the models due to the absence of in-case variation, an occurrence particularly likely with the German and Scandinavian categories which have, respectively, seven and four country-cases. Second, interpreting interaction variables is more complicated that interpreting the coefficients of individual variables in OLS regression. Specifically, the coefficient of the main effect of must be added to the coefficient of the secondary effect (Hardy, 1993: 29ff).

11 This approach is often referred to as "Granger Causality" (Granger, 1969; Levitt; Miles, 2006).

12 As a result of space considerations and a desire to present as concise an analysis as possible, only a small selection of the more interesting regression models are presented in this piece. Please contact the author directly to obtain the full set of models. 


\section{Analysis}

\section{A. Education}

A snapshot of public expenditures on education disaggregated by the constitutional status of the right to education (shown in Table 2) indicates a negative relationship between the constitutional "strength" of the right and governments' expenditures on education as both a percentage of total government expenditures and as a percentage of GDP. The pattern is suggestive, but the differences are not statistically significant. However, this does not control for the length of times the right has been in force or and fundamental differences between the jurisdictions which have and have not entrenched the right.

Table 2. Public Expenditures on Education, 2013

\begin{tabular}{|c|c|c|c|c|c|c|c|c|}
\hline \multirow{4}{*}{$\begin{array}{r}\begin{array}{c}\text { Right to } \\
\text { Education }\end{array} \\
\text { Absent }\end{array}$} & \multicolumn{8}{|c|}{ as a percentage of } \\
\hline & \multicolumn{4}{|c|}{ Government Expenditures } & \multicolumn{4}{|c|}{ GDP } \\
\hline & \multirow{2}{*}{$\begin{array}{r}\text { Mean } \\
15.5\end{array}$} & \multirow{2}{*}{$\begin{array}{c}\text { Std. Error } \\
1.29\end{array}$} & \multicolumn{2}{|c|}{ 95\% Confidence } & \multirow{2}{*}{$\frac{\text { Mean }}{5.1}$} & \multirow{2}{*}{$\frac{\text { Std. Error }}{0.40}$} & \multicolumn{2}{|c|}{ 95\% Confidence } \\
\hline & & & 13.0 & 18.1 & & & $4 \cdot 3$ & 5.9 \\
\hline Aspirational & 15.0 & 0.88 & 13.2 & 16.7 & 4.6 & 0.39 & 3.8 & 5.3 \\
\hline Justiciable & 14.6 & 0.53 & 13.6 & 15.6 & 4.5 & 0.18 & 4.2 & 4.9 \\
\hline
\end{tabular}

Source: World Development Indicators, TIESR

Employing the regression models described above on the five relevant dependent variables ${ }^{13}$ offers a slightly of a different picture. Neither the aspirational or justiciable variants of the right to education are directly and significantly correlated with education spending as a percentage of government expenditure. There is, however, a suggestion that the entrenchment of the right to education in partly free and not free countries is negatively correlated with the measure. Interestingly, there is a consistently positive correlation between education expenditures as a percentage of government expenditure and a Freedom House classification of "Not Free." When lagged a single year, the right to education in common law jurisdictions is negatively correlated with public expenditures on education as a percentage of GDP, while the right to education in civil law jurisdictions is positively correlated with

13 Public expenditure on education as a percentage of government expenditures and as a percentage of GDP, youth literacy rate, net and gross primary school enrolment rates. 
the same. Overall, the evidence suggests little in the way of a relationship between education expenditures and the constitutionalization of the right to education, although there is some evidence that the entrenchment of the right in non-democracies leads to increased expenditures on education as a proportion of government spending, but decreased expenditures as a proportion of GDP .

Table 3. Ne t Primary Enrolment

\begin{tabular}{|c|c|c|c|c|}
\hline & \multicolumn{4}{|c|}{ Model } \\
\hline & 1 & 2 & 3 & 4 \\
\hline \multicolumn{5}{|c|}{ Right to Education } \\
\hline \multicolumn{5}{|l|}{ 3-year } \\
\hline Aspirational & 2.11 & & $4.25^{* * * *}$ & \\
\hline Justiciable & $10.63^{* *}$ & & $11.55^{* * *}$ & \\
\hline \multicolumn{5}{|l|}{ 5-year } \\
\hline Aspirational & & -1.89 & & 0.14 \\
\hline Justiciable & & 2.19 & & $-2.08^{*}$ \\
\hline \multicolumn{5}{|l|}{ ICESCR } \\
\hline \multicolumn{5}{|l|}{ Ratification } \\
\hline 3-year & 0.12 & & 0.4 & \\
\hline 5-year & & 0.81 & & 0.97 \\
\hline \multicolumn{5}{|l|}{ Reservation } \\
\hline 3-year & $-2.90^{*}$ & & $-3.38^{*}$ & \\
\hline 5-year & & $-4.96^{* * *}$ & & $-5.80^{* *}$ \\
\hline \multicolumn{5}{|l|}{ Objection } \\
\hline 3-year & 2.8 & & 3 & \\
\hline 5-year & & 1.43 & & 2.14 \\
\hline \multicolumn{5}{|c|}{ Education Reservation } \\
\hline 3-year & $6.27^{* * *}$ & & $6.63^{* * *}$ & \\
\hline 5-year & & $6.88^{* * *}$ & & $7.71^{* * *}$ \\
\hline \multicolumn{5}{|l|}{ Interactions } \\
\hline \multicolumn{5}{|c|}{ Civil-Aspirational } \\
\hline 3-year & & & $-5.61^{* *}$ & \\
\hline 5-year & & & & $-4.84^{* *}$ \\
\hline \multicolumn{5}{|c|}{ Civil-Justiciable } \\
\hline 3-year & & & -1.83 & \\
\hline 5-year & & & & $\begin{array}{l}7.2 \\
\text { (cont }\end{array}$ \\
\hline
\end{tabular}




\section{(continuação)}

\section{Mixed-Aspirational}

3-year

$19.34^{* * *}$

5-year

Mixed-Justiciable

3-year

(omitted)

5-year

(omitted)

\section{Controls}

GDP

Population

Partly Free

Not Free

Political Stability

Rule of Law

Control of Corruption

Constant

Observations

$\mathrm{R}^{2}$

Countries

${ }^{*} \mathrm{p}<.1 ;{ }^{* *} \mathrm{p}<.05 ;{ }^{* * *} \mathrm{p}<.01$

$7.16^{* *} \quad 9.34^{* * *}$

$9.4 \quad 7.02$

$0.96 \quad 1.12$

$\begin{array}{ll}1.36 & 0.08\end{array}$

$\begin{array}{llll}1.29 & 0.34 & 1.36 & 0.08\end{array}$

$-1.30^{*}-1.83^{*}$

$\begin{array}{ll}2.65^{*} & 2.09\end{array}$

$-1.35$

$-1.87^{* *}$

2.03

1.28

$\begin{array}{ll}-0.06 & 1.27\end{array}$

$-0.12$

$-6.64$

1321

0.20

0.17

0.20

172

In terms of the realization of the right to education, there is no significant relationship between the entrenchment of the right generally and either the youth literacy rate or gross primary enrolment. There are, however, indications of a positive correlation between the entrenchment of the right generally and net primary enrolment in combination with a negative relationship when aspirationally entrenched in civil law jurisdictions. Interestingly, while the ratification of the ICESCR is not significantly related to primary enrolment, gross or net, the registration of reservation is consistently negatively correlated with primary enrolment levels, at a 90\% confidence level for gross enrolment and three-year lagged net enrolment, and a 99\% confidence level for five-year lagged net enrolment. However, when the reservation directly concerns education, the relationship is positive, significant at the $99 \%$ confidence level across all models and of two to three times the magnitude of the negative coefficient associated with a generalized reservation. Although there is somewhat more evidence to support the existence of a significant relationship between the entrenchment of the right to education and its substantive realization, the findings are neither consistent nor robust. 


\section{B. Health}

As is the case with education, the snapshot of public expenditures on health disaggregated by the constitutional status of the right to health presented in Table 4 suggests a negative relationship between state expenditure on health and constitutionalization. Here, too, however, the differences are not statistically significant and is no control for the length of times the right has been in force or and fundamental differences between the jurisdictions which have and have not entrenched the right.

Table 4. Public Expenditures on Health, 2014

\begin{tabular}{|c|c|c|c|c|c|c|c|c|}
\hline \multirow{3}{*}{$\begin{array}{l}\text { Right to } \\
\text { Health }\end{array}$} & \multicolumn{8}{|c|}{ as a percentage of } \\
\hline & \multicolumn{4}{|c|}{ Government Expenditures } & \multicolumn{4}{|c|}{ GDP } \\
\hline & Mean & Std. Error & $95 \% \mathrm{C}$ & fidence & Mean & Std. Error & $95 \%$ & fidence \\
\hline Absent & 12.8 & 0.83 & 11.1 & 14.4 & 5.1 & 0.53 & 4.1 & 6.2 \\
\hline Aspirational & 11.6 & 0.76 & 10.1 & 13.1 & 4.2 & 0.42 & 3.4 & 5.0 \\
\hline Justiciable & 11.5 & 0.47 & 10.6 & 12.4 & 3.8 & 0.21 & 3.4 & 4.2 \\
\hline $\mathrm{N}$ & 188 & & & & 188 & & & \\
\hline
\end{tabular}

Source: World Development Indicators, TIESR

With a single year lag, the relationship between the entrenchment of the right to health and public expenditure on health is consistently and significantly correlated higher healthcare expenditures, although the magnitude of the relationship is greater in relationship to health expenditures as a percentage of total government expenditures. When a three-year lag is introduced, the direction of the relationship remains consistently positive, but only occasionally rises to a meaningful level of significance. The data also indicate a generalized trend in toward increasing government expenditures on healthcare. Surprisingly, population and GDP per capita tend to be negatively correlated with government expenditures on health.

Table 5. Public Expenditures on Health (\% of GDP)

Model

1

2

3

4

\section{Right to Health}

1-year

Aspirational

$0.71^{*}$

$-0.5$

Justiciable

$0.83^{* * *}$

$0.68^{* *}$ 
(continuação)

3-year

Aspirational

0.59

$-0.67$

Justiciable

$0.56^{*}$

0.20

\section{ICESCR}

Ratification

1-year

0.17

0.06

3-year

0.27

0.15

Reservation

1-year

0.21

0.29

3-year

$-0.18$

$-0.09$

Objection

1-year

0.01

$-0.02$

3-year

0.34

0.31

\section{Interactions}

Civil-Aspirational

1-year

3-year

$1.38^{* *}$

Civil-Justiciable

$1.31^{*}$

1-year

0.12

3-year

Mixed-Aspirational

1-year

$2.73^{* * *}$

3-year

Mixed-Justiciable

1-year

(omitted)

3-year

(omitted)

\section{Controls}

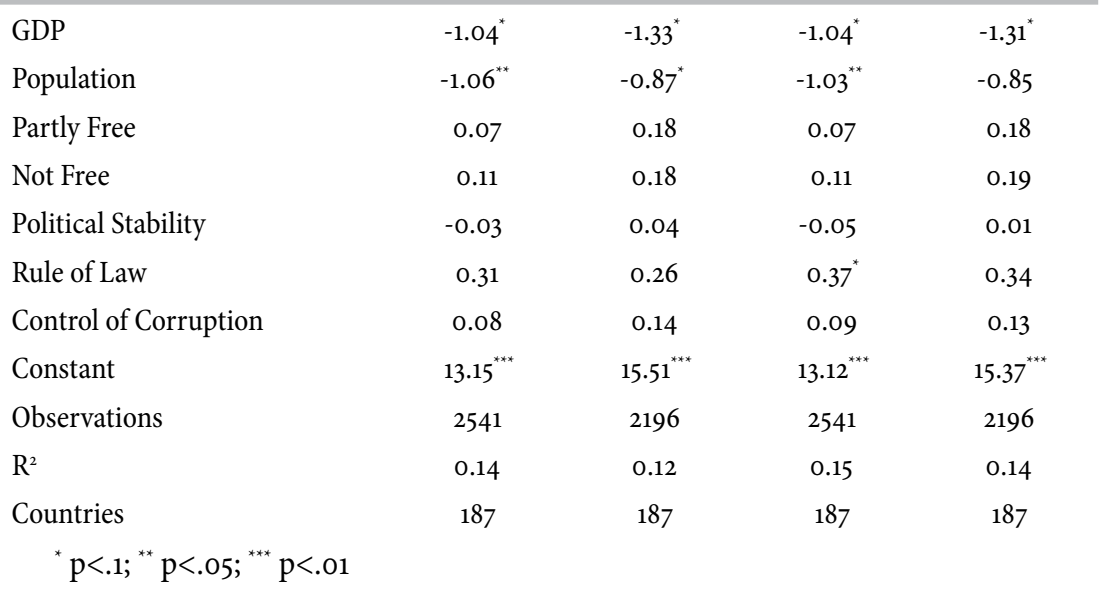


The direction of the relationship between the right to health and health outcomes is in line with the right having a beneficial impact (positive in relation to life expectancy, negative in relation to mortality rates), but the relationship is only statistically significant in a few instances. The most notable of these are in relation to infant and child mortality which. The ratification of the ICESCR in not significantly related to life expectancy, but there is a consistently significant pattern of reduced mortality rates in ratifying countries. In addition, the registration of a reservation is negatively and usually significantly associated with health outcomes across all three measures. Moreover, the effect size of a reservation is half again to twice the size of that of ratification. One possible explanation of this is that at least some countries are seeking the reputational benefits of ratification without the bother of realization. In line with the data on expenditures, there is a generalized trend of improved health outcomes over time. In contrast to health expenditures, however, GDP per capita and population are positively and significantly correlated with improved health outcomes. It is also noteworthy that, even after the introduction of rights and control variables, the regression models indicate as steady global increase in state healthcare expenditures of 0.1-0.3\% per year over 2000 levels, as well as steady annual increases in life expectancy and decreases in infant and under five mortality.

\section{Social Security}

In contrast to the negative, though statistically insignificant, pattern evident in cross-sectional data on education and health expenditures, there is no suggestion of correlation, let alone causation, between the constitutional status of the right to social security and post-tax and transfer income inequality (see Table 6).

Table 6. Income Inequality, 2010

\begin{tabular}{rcccc} 
Right to Social Security & Net Gini & Std. Err. & \multicolumn{2}{c}{$95 \%$ Confidence } \\
\hline Absent & 41.8 & 0.9 & 39.9 & 43.7 \\
Aspirational & 41.1 & 1.3 & 38.5 & 43.7 \\
Justiciable & 41.5 & 0.9 & 39.6 & 43.4 \\
\hline $\mathrm{N}$ & 105 & & &
\end{tabular}

Source: SWIID 5.1, TIESR

In general, the aspirational right to social security is positively and, for the most part, significantly correlated with decreased net income inequality with 
the justiciable variant of the rights is positively and somewhat less often significantly related with increased net income inequality. The exception to this trend is in where the right is entrenched aspirationally in countries with ties to the civil law tradition-including the "Socialist" category of the Laporta et al typology - where the right is correlated with higher levels of income inequality. There is no general trend in either direction with respect to time and inequality, but the political stability is consistently and significantly associated with lower inequality and the registration of a reservation when ratifying the ICESCR with higher inequality.

\section{Conclusion}

Although it does not support it, neither does the data presented here warrant outright rejection of the idea of social rights as "cheap talk" or "ceremony without substance." What it does do, however, is highlight the importance of understanding the political and economic factors conditioning social rights realization. This includes the need for the development of more fine-grained metrics of legal culture and political-legal institutions, perhaps with an eye toward mapping interpretive strategies adopted by courts and their effects in particular political-institutional settings. It also highlights the importance of having reasonable expectations about realizing; it is a complex, expensive task that occurs in the context of electoral politics, entrenched bureaucratic norms, and vested interests. As such, it ought to be evaluated with these things in mind, and interim goals-for example, increased expenditures in relevant areas-factored into analyses. Existing studies have also been hampered by missing data relating to a wide variety of relevant socio-demographic indicators. The gaps are unlikely to be randomly distributed and this must be borne in mind going forward. Finally, for better or for worse, economic logic tends to have a much greater influence on policymaking than rights- or morality-based arguments. Thus, independent of one's personal beliefs, the economic impacts of these rights merit study: at worst the argument for these rights is clarified-they are legal and moral imperatives and should be advocated on that basis. On the other hand, it may well be that the in the medium to long-term social rights have a net positive impact or, perhaps more probably, that their positive externalities yield a substantially lower net cost than a standard neoclassical account would predict, making that realization a less formidable challenge. 


\section{Appendix 1: Variable Reference Table}

\begin{tabular}{|c|c|c|c|c|c|}
\hline varname & Label \& Description & Coding/Metric & Years & Obs (\#) & Source \\
\hline country & Country Name & - & - & & TIESR \\
\hline ctrycode & $\begin{array}{l}\text { ISO Country Code ( } 3 \\
\text { character) }\end{array}$ & - & - & & TIESR \\
\hline year & Country-Year & - & 2000-2015 & 3088 & TIESR \\
\hline jg3 & $\begin{array}{l}\text { Legal System of } \\
\text { country }\end{array}$ & $\begin{array}{l}\text { 1-Common Law } \\
\text { 2-Civil Law } \\
\text { 3 Non-European \& } \\
\text { Mixed }\end{array}$ & 2000-2015 & 3088 & JuriGlobe \\
\hline laporta & $\begin{array}{l}\text { Legal Tradition of } \\
\text { country }\end{array}$ & $\begin{array}{l}\text { 1-Common Law [uk]; } \\
\text { 2-French Civil Law } \\
\text { [french]; } \\
\text { 3-Socialist [social]; } \\
\text { 4-German Civil Law } \\
\text { [german]; } \\
\text { 5-Scandinavian Law } \\
\text { [scand] }\end{array}$ & 2000-2015 & 3040 & LLSV \\
\hline \multicolumn{6}{|c|}{ Constitutional Provisions } \\
\hline educ & Right to Education & $\begin{array}{l}\text { o- Absent, } 1 \text { - Aspi- } \\
\text { rational, } 2 \text { - Justi- } \\
\text { ciable }\end{array}$ & 2000-2015 & 3083 & TIESR \\
\hline hlth & Right to Health & " & " & “ & TIESR \\
\hline $\operatorname{ssec}$ & $\begin{array}{l}\text { Right to Social Se- } \\
\text { curity }\end{array}$ & “ & “ & “ & TIESR \\
\hline \multicolumn{6}{|c|}{ International Treaties } \\
\hline icescr_d & ICESCR ratification $^{1}$ & $\begin{array}{l}\text { o-not ratified; 1-ra- } \\
\text { tified }\end{array}$ & 2000-2015 & 3120 & UNTC \\
\hline icescr_r & $\begin{array}{l}\text { Declaration or Reser- } \\
\text { vation re: ICESCR }\end{array}$ & $\begin{array}{l}\text { o-no; 1-reservation/ } \\
\text { declaration }\end{array}$ & 2000-2015 & 3120 & UNTC \\
\hline icescr_o & $\begin{array}{l}\text { Objections to Decla- } \\
\text { ration or Reservation } \\
\text { re: } \text { ICESCR }^{3}\end{array}$ & o-no; 1-objection & 2000-2015 & 3120 & UNTC \\
\hline res_educ & & $\begin{array}{l}\text { o-no; 1-reservation/ } \\
\text { declaration }\end{array}$ & 2000-2015 & 3120 & UNTC \\
\hline \multicolumn{6}{|c|}{ World Bank Governance Indicators } \\
\hline stable & $\begin{array}{l}\text { Political Stability and } \\
\text { Absence of Violence/ } \\
\text { Terrorism }\end{array}$ & $\begin{array}{l}\text { Ranges from approxi- } \\
\text { mately - } 2.5 \text { (weak) } \\
\text { to } 2.5 \text { (strong) gover- } \\
\text { nance performance }\end{array}$ & $\begin{array}{l}2000- \\
2015^{\mathrm{a}}\end{array}$ & 3066 & WBGI \\
\hline rule & Rule of Law & “ & “ & 3097 & “ \\
\hline corrupt & Control of Corruption & “ & “ & 3067 & “ \\
\hline
\end{tabular}


(continuação)

\begin{tabular}{|c|c|c|c|c|c|}
\hline varname & Label \& Description & Coding/Metric & Years & Obs (\#) & Source \\
\hline \multicolumn{6}{|c|}{ Economic Structure } \\
\hline popn & Population & $1,000,000 s$ & $2000-2015$ & 3116 & WDI \\
\hline lnpop & $\begin{array}{l}\text { Natural Log of Popn * } \\
1,000,000\end{array}$ & & “ & “ & Calculation \\
\hline gdppc & GDP per capita & constant 2010 US\$ & $2000-2015$ & 2978 & WDI \\
\hline $\operatorname{lngdp}$ & Natural Log of gdppc & & “ & “ & calculation \\
\hline \multicolumn{6}{|c|}{ Education Indicators } \\
\hline educ_gdp & $\begin{array}{l}\text { Public spending on } \\
\text { education }\end{array}$ & $\%$ of GDP & $2000-2015$ & 1691 & WDI \\
\hline educ_gov & $\begin{array}{l}\text { Public spending on } \\
\text { education }\end{array}$ & $\begin{array}{l}\text { \% of government } \\
\text { expenditure }\end{array}$ & “ & 1642 & WDI \\
\hline lit_yth & Literacy rate, youth & $\begin{array}{l}\% \text { of people ages } \\
15-24\end{array}$ & “ & 611 & WDI \\
\hline prim_g & $\begin{array}{l}\text { Primary school enrol- } \\
\text { ment, gross }\end{array}$ & $\begin{array}{l}\% \text { gross (may result } \\
\text { in values }>100 \text { ) }\end{array}$ & “ & 2507 & WDI \\
\hline prim_n & $\begin{array}{l}\text { Primary school en- } \\
\text { rollment, net }\end{array}$ & $\%$ net & “ & 1948 & WDI \\
\hline \multicolumn{6}{|c|}{ Health Indicators } \\
\hline hlth_pub & $\begin{array}{l}\text { Health expenditure, } \\
\text { public }\end{array}$ & $\%$ of GDP & $2000-2015$ & 2818 & WDI \\
\hline hlth_gov & $\begin{array}{l}\text { Health expenditure, } \\
\text { public (\% of govern- } \\
\text { ment expenditure) }\end{array}$ & $\begin{array}{l}\% \text { of government } \\
\text { expenditure }\end{array}$ & “ & 2813 & WDI \\
\hline lex & $\begin{array}{l}\text { Life expectancy at } \\
\text { birth, total }\end{array}$ & years & " & 2963 & WDI \\
\hline infant & Mortality rate, infant & per 1,000 live births & " & 3072 & WDI \\
\hline under & $\begin{array}{l}\text { Mortality rate, under } \\
\text { five }\end{array}$ & & “ & 3056 & WDI \\
\hline \multicolumn{6}{|c|}{ Social Security } \\
\hline gini_net & $\begin{array}{l}\text { Net (Post Tax \& } \\
\text { Transfer) Gini }\end{array}$ & $\begin{array}{l}\text { 0-100 (higher }=\text { less } \\
\text { equal) }\end{array}$ & $2000-2015$ & 1753 & SWIID 5.1 \\
\hline
\end{tabular}

${ }^{1}$ The Czech Republic and Slovakia; Bosnia \& Herzegovina, Croatia, FYR Macedonia, Montenegro, Serbia and Slovenia; Belize; and, Solomon Islands coded as non-ratifying until positive action to ratify/accede/succeed.

${ }^{2}$ Excludes declarations relating to Israel's status as a state.

${ }^{3}$ Excludes Israeli objections to declarations relating to Israel's status as a state.

${ }^{4}$ No data for Taiwan.

${ }^{a}$ Values for 2001 obtained by averaging 2000 and 2002 values 


\section{Data Sources}

\begin{tabular}{|l|l|l|}
\hline Abbreviation & Data Source & Web \\
\hline JuriGlobe & $\begin{array}{l}\text { World Legal Systems Research } \\
\text { Group }\end{array}$ & http://www.juriglobe.ca/eng/index.php \\
\hline LLSV & La Porta et al 2008 & $\begin{array}{l}\text { http://faculty.tuck.dartmouth.edu/rafael- } \\
\text {-laporta/research-publications }\end{array}$ \\
\hline SWIID & $\begin{array}{l}\text { Standardized World Income } \\
\text { Inequality Database }\end{array}$ & $\begin{array}{l}\text { http://myweb.uiowa.edu/fsolt/swiid/ } \\
\text { swiid.html }\end{array}$ \\
\hline TIESR & $\begin{array}{l}\text { Toronto Initiative for Economic } \\
\text { and Social Rights }\end{array}$ & http://www.tiesr.org/ \\
\hline UNTC & United Nations Treaty Collection & https://treaties.un.org/ \\
\hline WBGI & World Bank Governance Indicators & $\begin{array}{l}\text { http://info.worldbank.org/governance/ } \\
\text { wgi/index.aspx\#home }\end{array}$ \\
\hline WDI & $\begin{array}{l}\text { World Development Indicators } \\
\text { (World Bank) }\end{array}$ & $\begin{array}{l}\text { http://data.worldbank.org/data-catalog/ } \\
\text { world-development-indicators }\end{array}$ \\
\hline
\end{tabular}

\section{Works Cited}

ACEMOGLU, Daron, et al. (2001) "The Colonial Origins of Comparative Development: An Empirical Investigation," 91 American Economic Review 1369-1401.

ACKERMAN, Bruce A (1991) We the People: Foundations. Cambridge, Mass.: Harvard University Press.

ALLISON, Paul D. (2009) Fixed Effects Regression. Quantitative Applications in the Social Sciences SAGE.

“BARRO-LEE Educational Attainment Dataset," (n.d.), http://barrolee.com/ (accessed 15 February 2014).

BAUMGARTNER, Frank, \& Bryan D. Jones (1993) Agendas and Instability in American Politics. Chicago: University of Chicago Press.

BEN-BASSAT, Avi, \& Morri Dahan (2008) "Social Rights in the Constitution and in Practice," 36 Journal of Comparative Economics 103-119.

BJORNSKOV, Christian, \& Jacob Mchangama (2013) Do Social Rights Affect Social Outcomes?. Economics Working Papers Aarhus University.

BORGES, Danielle (2014) Individual Inputs and Collective Outputs: Understanding the Structural Effects of Individual Litigation on Healthcare in Brazil. Working Paper, FGV Direito Rio.

BREWER-CARÍAS, Allan R. (2008) Constitutional Protection of Human Rights in Latin America: A Comparative Study of the Amparo Proceeding. New York: Cambridge University Press. 
BRINKS, Daniel M, \& Varun Gauri (2012) Law's Majestic Equality? The Distributive Impact of Litigating Social and Economic Rights. Policy Research Working Paper, The World Bank Development Research Group.

BRINKS, Daniel M., \& Varun Gauri (2014) “The Law's Majestic Equality? The Distributive Impact of Judicializing Social and Economic Rights," 12 Perspectives on Politics 375-93.

"CHAPTER IV(3) International Covenant on Economic, Social and Cultural Rights: Ratification Status," (2014) United Nations Treaty Collection.

CHOUDHRY, Sujit (2006) The Migration of Constitutional Ideas. Cambridge: Cambridge University Press.

COLE, Wade M. (2013) "Strong Walk and Cheap Talk: The Effect of the International Covenant of Economic, Social, and Cultural Rights on Policies and Practices," 92 Social Forces 165-94.

(2015) "International Human Rights and Domestic Income Inequality A Difficult Case of Compliance in World Society," 80 American Sociological Review 359-90. CORBETT, Bob, ed. (1999) "Second Constitution of Haiti (Hayti) May 20, 1805." COUTINHO, Maria Laura (2014) Do Brazilian Courts Contribute to the Implementation of the Right to Housing?. Research Paper Series, Fundação Getulio Vargas.

DJANKOV, Simeon, et al. (2003) “The New Comparative Economics," 31 Journal of Comparative Economics 595-619.

ELKINS, Zachary, et al. (2008) The Comparative Constitutions Project: A CrossNational Historical Dataset of Written Constitutions. Survey Instrument, . . (2010) "Diffusion and the Constitutionalization of Europe", 43 Comparative Political Studies 969-99.

ESPING-ANDERSEN, Gosta (1985) "Power and Distributional Regimes," 14 Politics and Society 223-56.

FERRAZ, Octavio Luiz Motta (2011) "Brazil: Health Inequalities, Rights, and Courts: The Social Impact of the Judicialization of Health," in A. E. Yamin and S. Gloppen, eds., Litigating Health Rights: Can Courts Bring More Justice to Health? Harvard Law School Human Rights Program Series Cambridge, Mass.: Harvard University Press. GALANTER, Marc (1974) "Why the Haves Come out Ahead: Speculations on the Limits of Legal Change," 9 Law \& Society Review 95-160.

GAURI, Varun, \& Daniel M. Brinks, eds. (2008) Courting Social Justice: Judicial Enforcement of Social and Economic Rights in the Developing World. New York: Cambridge University Press. 
GERSCHENKRON, Alexander (1962) "Economic Backwardness in Historical Perspective," Economic Backwardness in Historical Perspective: A Book of Essays. Cambridge, Mass.: Belknap Press of Harvard University Press.

GETGEN, Jocelyn E, \& Benjamin Mason Meier (2009) "Ratification of Human Rights Treaties: The Beginning Not the End," 374 The Lancet 447-48.

GRANGER, C. W. J. (1969) "Investigating Causal Relations by Econometric Models and Cross-Spectral Methods," 37 Econometrica 424-38.

HAFNER-BURTON, Emilie M., \& Kiyoteru Tsutsui (2005) "Human Rights in a Globalizing World: The Paradox of Empty Promises," 110 American Journal of Sociology 1373-1411.

HARDY, Melissa A. (1993) Regression with Dummy Variables. Quantitative Applications in the Social Sciences SAGE.

HATHAWAY, Oona A. (2002) "Do Human Rights Treaties Make a Difference?” 111 The Yale Law Journal 1935-2042.

. (2007) "Why Do Countries Commit to Human Rights Treaties?") 51 Journal of Conflict Resolution 588-621.

HEYWOOD, Mark (2009) “South Africa's Treatment Action Campaign: Combining Law and Social Mobilization to Realize the Right to Health," 1 Journal of Human Rights Practice 14-36.

HOFFMAN, Steven J., \& John-Arne Røttingen (2015) "Assessing the Expected Impact of Global Health Treaties: Evidence from 90 Quantitative Evaluations," 105 American Journal of Public Health 26-40.

HOHMANN, Jessie (2013) The Right to Housing: Law, Concepts, Possibilities. Portland, Or.: Hart Publishing.

JUNG, Courtney, et al. (2014) "Economic and Social Rights in National Constitutions," 62 American Journal of Comparative Law 1043-93.

JUNQUIERA, Eliane Botelho (2003) "Brazil: The Road to Conflict Bound for Total Justice," in L. M. Friedman and R. Pérez-Perdomo, eds., Legal Culture in the Age of Globalization: Latin America and Latin Europe. Stanford: Stanford University Press.

KAUFMANN, Daniel, et al. (2010) The Worldwide Governance Indicators: A Summary of Methodology, Data and Analytical Issues. Working Paper, World Bank Policy Research.

KAVANAGH, Matthew M. (2016) "The Right to Health: Institutional Effects of Constitutional Provisions on Health Outcomes," 51 Studies in Comparative International Development 328-64. 
KEITH, Linda Camp (1999) “The United Nations International Covenant on Civil and Political Rights: Does It Make a Difference in Human Rights Behavior?", 36 Journal of Peace Research 95-118.

KING, Jeff (2012) Judging Social Rights. Cambridge Studies in Constitutional Law Cambridge University Press.

LA Porta, Rafael, et al. (2008) "The Economic Consequences of Legal Origins," 46 Journal of Economic Literature 285-332.

LANGFORD, Malcolm, ed. (2008) Social Rights Jurisprudence: Emerging Trends in International and Comparative Law. Cambridge, UK: Cambridge University Press. LEVITT, Steven D., \& Thomas J. Miles (2006) "Economic Contributions to the Understanding of Crime," 2 Annual Review of Law and Social Science 147-67.

MCCANN, Michael W. (1994) Rights at Work: Pay Equity Reform and the Politics of Legal Mobilization. University of Chicago Press.

NEUMAYER, Eric (2005) "Do International Human Rights Treaties Improve Respect for Human Rights?" 49 Journal of conflict resolution 925-953.

PALMER, Alexis, et al. (2009) "Does Ratification of Human-Rights Treaties Have Effects on Population Health?," 373 The Lancet 1987-92.

PERJU, Vlad (2012) “Constitutional Transplants, Borrowing, and Migrations," in M. Rosenfeld and A. Sajo, eds., The Oxford Handbook of Comparative Constitutional Law. Oxford University Press.

PERRET, Louis, et al. (2008) World Legal Systems. JuriGlobe Research Group, University of Ottawa.

PIERSON, Paul (2000) "Increasing Returns, Path Dependence, and the Study of Politics," 94 American Political Science Review 251-67.

PINZON-RONDON, Angela Maria, et al. (2015) "Association of Rule of Law and Health Outcomes: An Ecological Study," 5 BMJ open eoo7004.

PIOVESAN, Flavia (2008) "Brazil: Impact and Challenges of Social Rights in the Courts," in M. Langford, ed., Social Rights Jurisprudence: Emerging Trends in International and Comparative Law. Cambridge University Press.

"POLITICAL Constitution of the Peruvian Republic, 1828," (1832) 16 British and Foreign State Papers 966-88.

PRADO, Mariana, \& Michael J Trebilcock (2009) "Path Dependence, Development, and the Dynamics of Institutional Reform," 59 University of Toronto Law Journal 341-79. RANDOLPH, Susan, et al. (2010) "Economic and Social Rights Fulfillment Index: Country Scores and Rankings," 9 Journal of Human Rights 230-61.

RENNER, Karl (2010) The Institutions of Private Law and Their Social Functions. Transaction Publishers. 
RODRÍGUEZ Garavito, César A.., \& Diana Rodríguez Franco (2015) Radical Deprivation on Trial: The Impact of Judicial Activism on Socioeconomic Rights in the Global South. New York: Cambridge University Press.

RODRÍGUEZ-GARAVITO, César (2011) "Beyond the Courtroom: The Impact of Judicial Activism on Socioeconomic Rights in Latin America," 89 Texas Law Review 1669-98.

ROSENBERG, Gerald N. (2008) The Hollow Hope: Can Courts Bring About Social Change?. Chicago: University of Chicago Press.

ROUX, Theunis (2013) The Politics of Principle: The First South African Constitutional Court, 1995-2005. Cambridge: Cambridge University Press.

SCHERER, Bonnie A. (2004) "Footing the Bill for a Sound Basic Education in New York City: The Implementation of Campaign for Fiscal Equity v. State," 32 Fordham Urb. LJ 901.

SCOTT, Craig, \& Philip Alston (2000) "Adjudicating Constitutional Priorities in a Transnational Context: A Comment on Soobramoney's Legacy and Grootboom's Promise," 16 South African Journal on Human Rights 206.

SILVA, Virgilio Afonso da, \& Fernanda Vargas Terrazas (2011) "Claiming the Right to Health in Brazilian Courts: The Exclusion of the Already Excluded?" 36 Law \& Social Inquiry $825-853$.

SOLT, Frederick (2016) "The Standardized World Income Inequality Database," 97 Social Science Quarterly 1267-81.

WANG, Daniel Wei L. (2015) "Right to Health Litigation in Brazil: The Problem and the Institutional Responses," 15 Human Rights Law Review 617-41.

YOUNG, Katharine G. (2012) Constituting Economic and Social Rights. Oxford University Press.

Recebido em 30/05/2017

Aprovado em 10/06/2017

\section{Como citar este artigo:}

EVAN, Rosevear. Realizing social rights: the material impacts of constitutional entrenchment. Contemporânea - Revista de Sociologia da UFSCar, v. 7, n. 2, jul.- dez. 2017, pp. 313-340. 